\title{
Effects of Vermi-compost and Two Bacterial Bio- fertilizers on some Quality Parameters of Petunia
}

\author{
Mina Zarghami MOGHADAM ${ }^{1}$, Mahmud SHOOR² \\ ${ }^{1}$ Ferdowsi University of Mashhad, International Campus, Vakilabad Hwy, Mashhad 9177948974, Iran \\ ${ }^{2}$ Ferdowsi University of Mashhad, Horticulture Department, Vakilabad Hwy, Mashhad 9177948974, Iran
}

\begin{abstract}
The present research was conducted to study the effect of vermi-compost and two bio-fertilizer applications on growth, yield and quality of petunia (Petunia hybrida). The experiment laid out in randomized block design with 3 replications and 9 treatment combinations composing of vermi-compost, bio-fertilizers and NPK fertilizer. The treatment receiving Azospirillum sp. + Phosphate solubilizing bacterium + Vermicompost + NPK ( $25 \%$ of recommended dose) recorded the highest plant height, number of branches, plant spread, leaf area index, dry matter accumulation and yield attributes such as number of flowers per plant, number of flowers per plot, flower yield/plant, flower yield/plot. The early flower bud initiation, 50 percent flowering and more flowering duration was achieved in the treatment receiving Azospirillum sp. + Phosphate solubilizing bacterium + Vermicompost + NPK (25\% of recommended dose) Application of Azospirillum sp. + Phosphate solubilizing bacterium + Vermicompost + NPK (25\% of recommended dose) registered significantly higher quality parameters such as flower diameter.
\end{abstract}

Keywords: Azospirillum sp., NPK, phosphate solubilizing bacterium, vermicompost

\section{Introduction}

Increased flower production, quality of flowers and perfection in the form of plants are the important objectives to be recognized in bedding and flower production. Boodley (1975) considered quality to be a function of nutrient level. Though nitrogen, phosphorus and potassium influence the production and quality of flowers greatly, the fertilizers recommendation is very high which reflects directly on cost of production. In addition, use of synthetic fertilizers and chemicals in high ranges possess environmental pollution problem with potential hazards to flora and fauna and also on human beings.

The common garden petunia, Petunia hybrida, is derived from $P$. integrifolia and $P$. axillaris, two of many Petunia species endemic to South America. Petunia comprises annual or perennial herbs, up to $1 \mathrm{~m}$ tall, with erect, ascendant, decumbent, or procumbent stems, rarely rooting at the nodes. The leaves are sessile or petiolate, with blades elliptic, ovate or obovate, more rarely rounded or linear, membranaceous, somewhat juicy, flat, and usually without marked venation.

Total organic farming may be a desirable proposition for improving the quality of agricultural produce. It may not be possible to maintain the quality of produce in commercial agriculture, where mostly the stress will be given mainly on yield. It is impossible to meet the nutritional requirement of the crops, exclusively through the organic farming. Under these circumstances, integrated soil fertili- ty management practices involving judicious combination of organic manures, biofertilizers and chemical fertilizers seems to be a feasible option for sustained agriculture on a commercial and profitable scale. In addition, they are ecofriendly, easily available and cost effective. Therefore, emphasis is now focused on the use of organic manures such as compost, vermicompost, farm yard manures and biofertilizers like Azotobacter, Azospirillum and phosphate solubilizing bacteria (PSB). Earthworms utilize organic wastes as food and the undigested material excreted by them has gained the name 'vemicompost'. The vermicompost serves as organic manure, since it is a source of nutrients, such as nitrogen, phosphate, potassium, humic acids and micronutrients. Bio-fertilizers or more appropriately called 'microbial inoculants' are the preparations containing live or latent cells of efficient strains of micro-organisms. These may be biological nitrogen fixers, P-solubilizing, mineralization of nitrogen and transformation of several elements like sulphur and iron into available forms. These bio-fertilizers benefit agricultural production by supplying nutrients. Common bio-fertilizers used in horticultural crops are Azotobacter, Azospirillum, phosphate solubilizing bacteria and VAM fungi. Azospirillum is a symbiotic $\mathrm{N}$-fixing bacterium. Azotobacter and Azospirillum fix atmospheric nitrogen when inoculated to plants, which help to save the application of $\mathrm{N}$ - fertilizers to an extent of 20-25 per cent. Recently, lot of emphasis has been given to the possibility of utilizing indigenously available rock phosphate. By the addition of $\mathrm{PSB}$, the unavailable form of $\mathrm{P}$ is converted to 
the available form, increasing $\mathrm{P}$ uptake and leading to increased yields.

Vermicompost besides being a rich source of micronutrients, also act as chelating agent and regulates the availability of metabolic micronutrients like iron and zinc to the plants and increases the plant growth and yield by providing nutrients in the available form. It is also cost- effective organic manure. Use of vermicompost in agriculture was first reported by (Hopp and Slater, 1979). Further, they quantified the response of crop to earthworms in terms of yield.

Kale et al. (1987) in salvia and ornamental plants reported that reduction in the fertilizer levels was made up with the vermicompost application without any loss of yield owing to P. mineralization due to symbiotic mycorrhizal association. The significant increase in the leaf area index and flowering was also observed due to vermicompost application. Nethra (1996) recorded the maximum plant height, number of leaves, number of flowers per plant and flower yield per hectare due to the application of vermicompost 10 tonnes per hectare and recommended dose of NPK in China aster. In the same crop, application of vermicompost and farm yard manure with recommended NPK increased the plant height, number of leaves, number of branches and flower yield. Gangadharan and Gopinath (2000) reported that application of vermicompost 10 t ha $^{-1}+80$ per cent recommended NPK dosage resulted in better growth with higher flower yield and quality of gladiolus cut flowers. Importance of vermicompost was also reported by (Atiyeh et al., 2000) where relatively low concentration of vermicompost produced better plant growth in marigold. Ajitkumar (2002) reported that in marigold the maximum plant height, number of branches, number of leaves, more diameter of flower $(7.70 \mathrm{~cm})$, number of flowers per plant and flower yield per hectare due to application of vermicompost $10 \mathrm{t} \mathrm{ha}^{-1}+$ recommended NPK. Narayanagowda (2003) in china aster reported that application of vermicompost along with reduced dose of chemical fertilizers had beneficial effects on growth and yield parameters as compared to application of inorganic fertilizers alone (Bashan, 2004).

Maximum numbers of flower buds/plant, individual flower weight and flower yield $/ \mathrm{m}^{2}$ was recorded with application of vermicompost at $1000 \mathrm{~g} / \mathrm{m}^{2}$ in marigold (Chauhan et al., 2005). Balaji et al. (2006) reported that the application of vermicompost $(2.5-5 \mathrm{t} / \mathrm{ha})$ helped to reduce the inorganic fertilizer requirement of China aster crop to the tune of 25-50 per cent without affecting the yield. Similarly, in situ vermiculture (2 lakhs earthworms/ ha) without any fertilizer also showed similar results as that of recommended practices (180:120:60 kg NPK/ha $+15 \mathrm{t} /$ ha farm yard manure).

Chaitra and Patil (2007) observed significant increase in plant height, number of leaves, number of branches, total dry matter production and also flower yield in china aster Cv. 'Kamini' with the application of vermicompost
2.5 t ha $^{-1}$ with 50 percent recommended dose of fertilizers. Warade et al. (2007) recorded that the growth of dahlia in respect of height of plant, number of leaves plant ${ }^{-1}$, spread of plant, earliness of flowering and yield of flowers was superior in the plants receiving vermicompost $500 \mathrm{~g}$ with PSB $25 \mathrm{~g} \mathrm{plot}^{-1}$.

Bio-fertilizers are beneficial microorganisms, which could lead to considerable change in the growth parameters of plants. Azospirillum is one among the commonly used biofertilizers. Azospirillum is a motile, gram negative, spiral shaped diazotropic bacterium, which lives in harmony with root tissues. Wild strain of Azospirillum fixes atmospheric nitrogen efficiently either as a free living bacterium or in combination with plants and thus participates in the nitrogen cycle (Tarrand et al., 1978). It is associated with root tissues and lives in harmony with root tissues, fixing substantial amount of nitrogen.

Balasubramanian (1989) reported increased growth in marigold inoculated with Azospirillum, this might be due to added nitrogen to crop through associative symbiosis and increased production of growth hormones like NAA, GA and cytokinins (Bashan, 2004). Preethi (1990) opined that the early flowering in rose by the inoculation of Azospirillum might be due to induced cytokinin synthesis and rapid assimilation of photosynthates resulting in early transformation of the axillary bud from vegetative to reproductive phase (Bashan, 2004). Wange et al. (1995) revealed the increase in number of bulblets (14.3/plant), flower stalks (23348 dozen/ha) with higher monetary returns (1.00:3.73) in tuberose Cv. 'Single' with Azospirillum inoculation. Prabhatkumar et al. (2003) reported that the increase in vegetative growth in China aster by bio-fertilizers was because of stimulation in nutrient uptake and biosynthesis of plant growth regulators, there by stimulating the growth and development process of the plant. Maximum leaf area, length of first order lateral shoots, number and weight of flowers $/ \mathrm{m}^{2}$ during first and second flush were observed with inoculation of Azotobacter treatment in rose (Singh, 2005).

In tuberose Cv. 'Mexican Single', combined application of NPK with Azospirillumand phosphobacteria resulted in higher spike length number of flowers per spike and flower yield compared to control (Swaminathan et al., 1999). Chandrikapure et al. (1999) found that local variety of African marigold produced significantly greater height in treatment with 100 per cent $\mathrm{N}+$ Azotobacter + phosphate solubilizing bacteria and higher flower yield per ha in treatment with Azotobacter + Phosphate solubilizing bacterium +75 percent N. Singh et al. (2003) reported that application of Phosphate solubilizing bacterium along with the chemical fertilizer increased significantly the flower yield in rose. Muzain et al. (2004) in gladiolus Cv. 'Snow Princes' revealed that the treatment having the application of VAM + Azospirillum + Phosphate solubilizing bacterium + Azotobactor was found better for the traits like early spike initiation, number of florets per 
228

spike, length and longevity of the spikes. Similar results were found with $\mathrm{Cv}$. 'American Beauty' in the same crop (Mansee and Ranjan, 2004).

In carnation, (Gupta et al., 2004) reported that the application of bio-fertilizers like VAM, Azospirillum, Phosphate solubilizing bacterium have registered maximum plant height, minimum number of days to first flowering, maximum bud and flower size, maximum vase life and maximum cost benefit ratio. Dubey and Misra (2006) reported that the dual inoculation of gladiolus corm with Azotobacter + Phosphate solubilizing bacterium was found best among all the bio-fertilizer treatment for early corm sprouting (15.75 days), increased number of leaves/ plant (8.39), leaf area $\left(316.13 \mathrm{~cm}^{2}\right)$, plant height $(21.99$ $\mathrm{cm}$ ), induced heading (91.90 days) and dry weight (24.13 g) over control. Chaitra and Patil (2007) observed significant increase in plant height, number of leaves, number of branches, total dry matter production and also flower yield in china aster Cv. 'Kamini' with the application of Phosphate solubilizing bacterium with 50 percent recommended dose of farm yard. In gaillardia, (Deshmukh et al., 2008) revealed that, significantly maximum vegetative growth viz., plant height, plant spread, diameter of main stem, 50\% flowering, diameter of flower, length of flower stalks, number of flowers and yield of flowers plant ${ }^{-1}$ and ha $\mathrm{a}^{-1}$ was increased in treatment $75 \% \mathrm{NPK}+$ seedling inoculation with Azotobactor + Phosphate solubilizing bacterium ( $500 \mathrm{~g}$ each 5 liter $^{-1}$ of water).

\section{Materials and methods}

This investigation aimed to evaluate effects of vermincompost and two bio-fertilizers on growth and flower production quality of petunia.

\section{Soil characters}

The soil of the experimental site was loamy sand in texture with neutral $\mathrm{pH}$ and low soluble salt content. The soil was low in available nitrogen, phosphorus and also in available potassium content.

\section{Experimental method}

The experiment was laid out by completely randomized block and treatments in each replication randomly allotted. Treatments were: A1: control, A2: recommended dose of NPK, A3: 100\% Vermicompost, A4: Azospirillum sp. + NPK (recommended dose), A5: Phosphate solubilizing bacterium + NPK (recommended dose), A6: Azospirillum sp. + Vermicompost, A7: Phosphate solubilizing bacterium + Vermicompost, A8: Azospirillum sp. + solubilizing bacterium + NPK ( $50 \%$ of recommended dose), A9: Azospirillum sp. + Phosphate solubilizing bacterium + Vermicompost + NPK (25\% of recommended dose).

Seed sowing and nursery operation: seeds of petunia sowed in seedling trays with 120 cells. Trays filled with coco peat + perlite without any fertigation. Seedling trays were watered every day after sowing and 12-14 days after sowing, seeds were germinated and 30 days after sowing petunia plugs were ready for transplanting.

Experimental plots preparation: the experiment was done in plastic pots $(15 \mathrm{~cm}$ (diameter $) \times 30 \mathrm{~cm}$ (height) $)$. In each treatment plot we had 10 pots (each one as a sample that was filled up with autoclaved loamy sand soil and its specific fertilization program) which were put together in the same condition and named 1 plot. Nine treatments randomly allotted together (in the same place for light) and named as a block (replication). Between plots we had $0.5 \mathrm{~m}$ space and between blocks we had $1 \mathrm{~m}$ space. Irigation schedule was daily except dose days in which temperature was higher than $35^{\circ} \mathrm{C}$, than was done twice a day.

Transplanting: Healthy and uniform seedlings were used for transplanting 30 days after sowing.

Application method of treatments: vermicompost was added 10 days before transplanting to the soil of any treatment than contains it that let decomposition got complete. biofertilizers added to medium while plugs transplanted. $15 \mathrm{ml}$ of each bio-fertilizer added to medium. Nitrogen, phosphorus and potassium were applied in the form of NPK liquid fertilizer.

Pest and disease management: plants were protected against possible pest and diseases by usual application methods.

Data collection: The observations on various parameters of vegetative and flowering were recorded at three stages of plant growth, 20, 40 and 65 days after transplanting. Plants in each stage tagged and numbered in order to make a developmental sheet of data for each plant.

Observated parameters: different growth related parameters observed like, plant height $(\mathrm{cm})$, number of branches per plant, plant spread $(\mathrm{cm})$. Also different parameters related to flowering yield were observed like, days to flower bud initiation from transplanting day, days to 50 per cent flowering, flowering duration, flower yield per plant $(\mathrm{g})$. Data of some quality parameters of flowers and changes in amount of $\mathrm{N}, \mathrm{P}$ and $\mathrm{K}$ in treated petunia plants also collected but data are not shown.

\section{Results and discussion}

\section{Plant height}

Plant height of petunia plants significantly varied by application of different treatments. Plant height at 20 DAT (days after transplanting) increased significantly from a maximum of $23.80 \mathrm{~cm}$ in treatment receiving A9 and it was on par with A2 $(23.37 \mathrm{~cm})$ and A7 $(22.90 \mathrm{~cm})$. However, minimum plant height $(17.67 \mathrm{~cm})$ was recorded in the control (A1). Plant height at $40 \mathrm{DAT}$, varied significantly among different treatment combinations. The plants receiving A9 treatment, recorded maximum plant height $(82.87 \mathrm{~cm})$ and found to be on par with A7 $(82.20$ $\mathrm{cm})$ and A2 $(73.80 \mathrm{~cm})$ treatments. The minimum plant 
height $(50.93 \mathrm{~cm})$ was recorded in control (Fig. 1). At 65 DAT the maximum plant height $(87.00 \mathrm{~cm})$ was recorded in the treatment receiving $\mathrm{A} 9$ nutrient combination and it was on par with A7 $(85.57 \mathrm{~cm})$ and A2 $(85.27 \mathrm{~cm})$. Plant height was significantly least in control $(70.67 \mathrm{~cm})$.

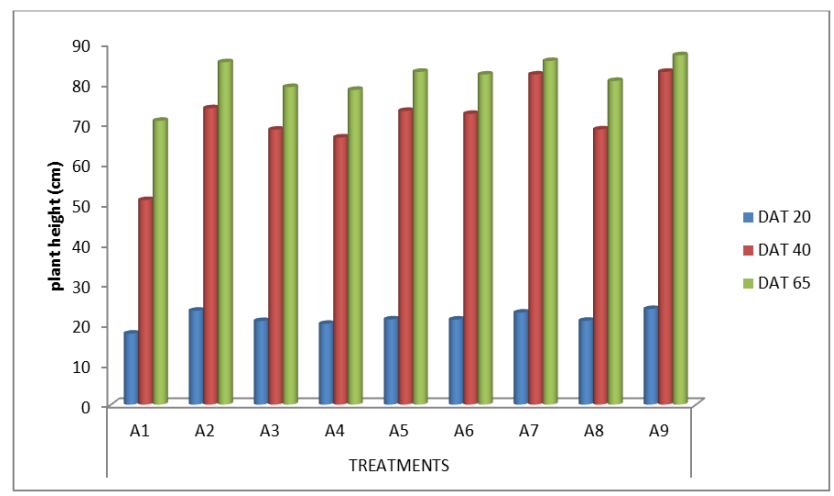

Fig. 1. Effects of different nutrient management methods on petunia height $(\mathrm{cm})$

The increase in the plant height in the treatment A9 might be due to the beneficial effects of vermicompost and biofertilizers and inorganic fertilizers. The decrease in the plant height may be due to unavailability of sufficient nutrients at critical developmental stages which decrease growth rate. Similar findings were reported by (Nethra, 1996) and (Ajitkumar, 2002) in China aster and marigold respectively. Chaitra and Patil (2007) observed significant increase in plant height of China aster applied with biofertilizers +NPK. Sunita et al. (2007) also noticed higher plant height with application of vermicompost in African marigold. Also, increased plant height of gaillardia was observed by (Deshmukh et al., 2008) by using NPK with biofertilizers as seedling inoculation.

\section{Number of branches per plant}

At 20 DAT the maximum number of branches (11.56) recorded significantly higher in application of A9 treatment which found to be on par with A7 (11.10) and A2 (10.27) treatments. Minimum number of branches (6.93) was recorded in the control treatment (Fig. 2). At 40 DAT the number of branches of different treatment varied significantly. The plants receiving A9 recorded significantly maximum number of branches (25.55) which was found to be on par with A7 (21.10). The minimum number of branches was observed in the control treatment (11.45). At 65 DAT significant differences with regard to number of branches was observed among different treatments. The maximum number of branches (39.61) was observed in the A9 treatment. It was on par with A7 (38.04) and A2 (37.39). However, the control had minimum number of branches (22.34).

These results for number of branches could be attributed because of better micro and macro nutrients flow along with plant growth substances into the plant system in the treatments applied with vermicompost and bio-fertilizers in combination with inorganic fertilizers. The growth regulators like NAA and cytokinins released by biofertilizers might have resulted in breaking of apical dominance and accelerated higher number of branches. The above results are collaborated with the findings of (Ajitkumar, 2002) in marigold and (Sunita et al., 2007) in African marigold. Similar trends in increased number of branches due to biofertilizer treatment were reported by (Chaitra and $\mathrm{Pa}$ til, 2007).

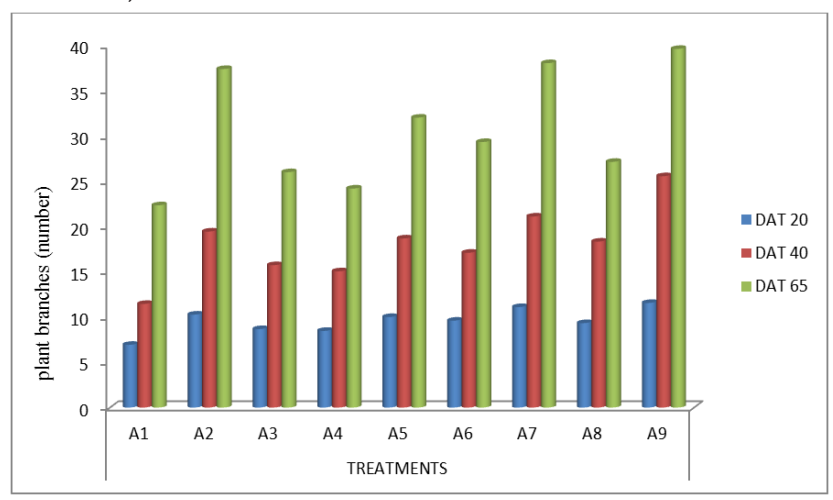

Fig. 2. Effects of different nutrient management methods on petunia branches (number)

\section{Plant spread}

At 20 DAT maximum plant spread was recorded in the A9 treatment followed by A7 and A2 and the minimum was happened in control treatment $(13.23 \mathrm{~cm})$ (Fig. $3)$. The similar trend was noticed at 40 and 65 DAT. The maximum plant spread (28.07 and $35.77 \mathrm{~cm}$ respectively) was recorded in the treatment $\mathrm{A} 9$ which was found to be on par with A7 $(25.87$ and $34.17 \mathrm{~cm})$ and A2 $(25.23$ and $34.03 \mathrm{~cm}$ ) and minimum was the control ( 14.60 and 21.00 $\mathrm{cm}$ respectively).

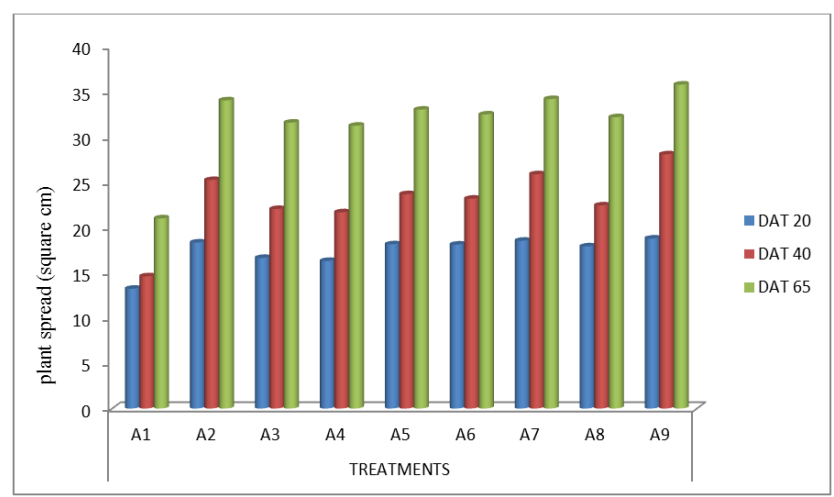

Fig. 3. Effect of different nutrient management methods on petunia spread (square $\mathrm{cm}$ )

Warade et al. (2007) also reported increased plant spread of dahlia plants receiving vermicompost along with biofertilizer. Deshmukh et al. (2008) observed significantly maximum plant spread of gaillardia by the application of NPK + biofertilizer seedling inoculation. 
230

Days to flower bud initiation

Significant differences were observed among the different treatments in Petunia for days to first flower bud initiation. In A9 where the plants were supplied with a combination of all treatments, was the first to show its visible flower bud which was on par with A7 and A2. However, control (A1) treatment was the last to initiate flower bud (31.67 DAT) (Fig. 4).

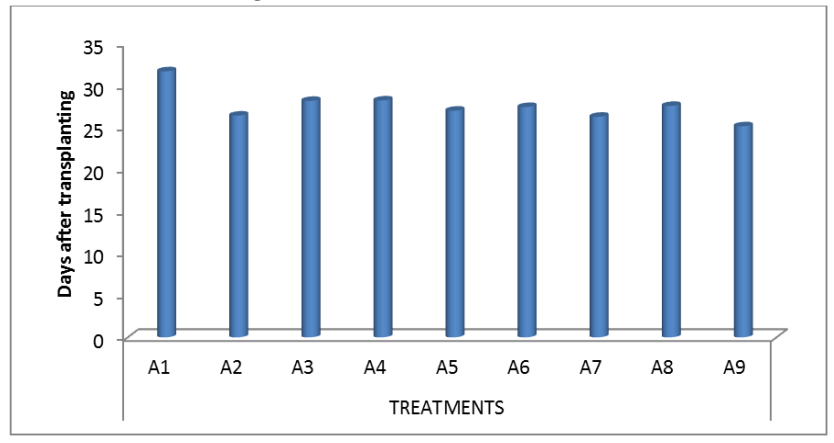

Fig. 4. Effects of different nutrient management methods on petunia $1^{\text {st }}$ flower bud initiation (Days after transplanting)

\section{Days to 50\% flowering}

The treatments which contain biofertilizers had significant effects on the number of days taken for 50 percent flowering. Between all the treatments, 50 per cent flowering was earliest in A9 which was significantly similar with A7. Maximum number of days to $50 \%$ flowering took place in A1 (Fig. 5).

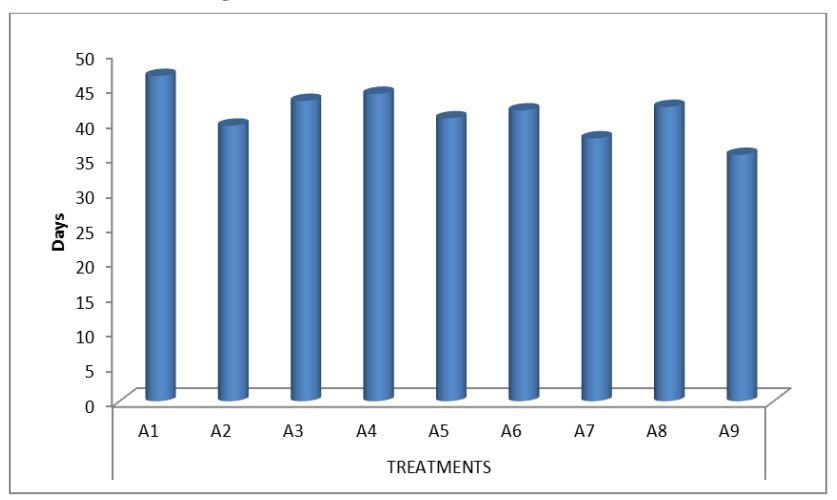

Fig. 5. Effects of different nutrient management methods on days to $50 \%$ of petunia full flowering (Days after transplanting)

\section{Duration of flowering}

The data showed in fig. revealed significant variation for flowering duration between different treatments. Plants treated with A9 recorded significantly maximum flowering duration. A7 treatment also had a long lasting flowering which was not significantly differ from A9. The minimum flowering duration was recorded in control (A1) (Fig. 6).

The earliness of flowering may be attributed to the presence of biofertilizers especially inoculation with Azosprillium and PSB which consequently lead to flower initiation and more flower duration. This may be due to easy uptake of nutrients and simultaneous transport of growth promoting substances like cytokinins to the axillary buds resulting in breakage of apical dominance. Ultimately, they resulted in better sink for faster mobilization of photosynthates and early transformation of plant parts from vegetative to reproductive phase. Similar findings were published by (Padaganur $e$ t al., 2005 ) in tuberose and (Mesharam, 2008) in chrysanthemum.

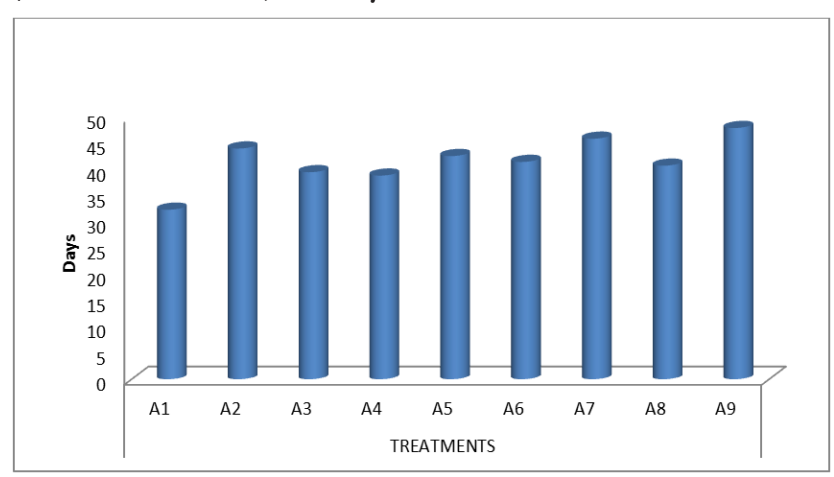

Fig. 6. Effects of different nutrient management methods on petunia flowering duation (Days after flowering)

\section{Flower yield per plant}

The data on flower yield per plant was significantly influenced by applied treatments. Application of A9 treatment gave significantly maximum flower yield per plant $(86.82 \mathrm{~g})$. However, minimum flower yield per plant (20.43 g/plant) was recorded in the control (Fig. 7).

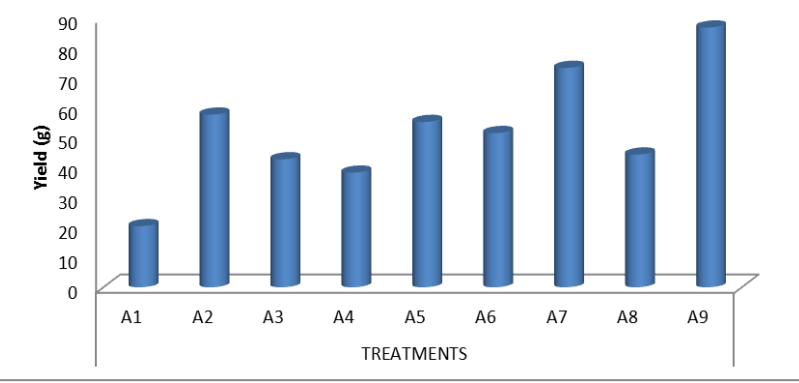

Fig. 7. Effects of different nutrient management methods on petunia flower yield per plant $(\mathrm{g})$

Increase in flower yield might be happened because of an increase in phosphorous availability and its greater uptake. While, vermicompost being the sufficient source of macro and micro nutrients like Fe and $\mathrm{Zn}$. Bio-fertilizers also increase the promotional substances in plant like PGRs and may be act like a supporting team for insurance of good flowering yield. Although, healthy growth of plants and greater number of branches and increased plant height may have prepare new flowering positions and increase flower number and flowering yield.

In similar investigations (Narasimha and Haripriya, 2001) reported higher flower yield in crossandra, (Chandrikapure et al., 1999) in marigold, (Deshmukh et al. 2008) in gaillardia and (Meshram et al., 2008) in chrysanthemum. 


\section{Conclusion}

In general, the growth of petunia plants were better when inorganic fertilizers were supplemented with Azospirillum, PSB and vermicompost in compare with control. Hence, the use of organic and bio fertilizers have a lot of beneficial effects apart from the increased yield and returns. it improves the soil structure and texture, reduces pollution of soil due to reduced fertilizer application which is beneficial for the present problems of high cost of fertilizers and environmental pollution.

\section{References}

Ajitkumar (2002). Effect of organic and inorganic fertilizers on growth, yield and post harvest life of marigold. M Sc (Agri) Thesis, Univ Agric Sci Dharwad.

Atiyeh RM, Edwads CA, Subler S, Metzer JD (2000). Earthworm processed organic wastes as components of Horticultural potting media for growing marigold and vegetable seedlings. Compost Sci Utilization 8:215-233.

Balaji S, Kulkarni M, Reddy BS, Patil BC, Divakara A (2006). Influence of vermicompost and in situ vermiculture on the quality attributes and saleable yield in china aster. Scientific Hort 10:217-221.

Bashan Y, Holguin G (2004). Azospirillum-plant relationships: physiological, molecular, agricultural, and environmental advances (1997-2003). Can J Microbiol 50(8):521-577.

Boodley JW (1975). Plant nutrition and flower quality. Horti Sci 10(1):41-48.

Chandrikapure KR, Sadawarte DM, Panchabh BD (1999). Effect of bioinoculants and graded doses of nitrogen on growth and flower yield of marigold (Tagetes erecta L.). The Orissa J Hort 27(2):31-34.

Chaitra R, Patil VS (2007). Integrated nutrient management studies in China aster (Callistephus chinensis Nees) Cv. 'Kamini'. Karnataka J Agril Sci 20(3):689-690.

Chauhan S, Singh CN, Singh AK (2005). Effect of vermicompost and pinching on growth and flowering in marigold $\mathrm{Cv}$. Pusa Narangi Gainda. Prog Hort 37(2):419-422.

Deshmukh PG, Khiratkar SD, Badge SA, Bhongle SA (2008). Effect of bioinoculants with graded doses of NPK on growth and yield of gaillardia. J Soils Crops 18(1):212-216.

Dubey RK, Misra RL (2006). Study of chemical and bio-fertilizers on gladiolus. Prog Hort 38(2):165-171.

Gangadharan GD, Gopinath G (2000). Effect of organic and inorganic fertilizers on growth, flowering and quality of gladiolus Cv. 'White Prosperity'. Karnataka J Agric Sci 11(3):401-405.

Gupta YC, Suman B, Sharma Y D, Thakur R, Ritu J (2004). Effect of growing media and fertilization on growth and flowering of carnation (Dianthus caryophyllus L.) under protected conditions. Natl Symp Rec Trends Future Strategies Orna Hort, 77 p.
Hopp H, Slatter CS (1979). The effect of earth worms on the productivity of agricultural soil. J Agric Res 78:325-329.

Kale RD, Bano K, Sreenivasa MN, Bagyaraj DJ (1987). Influence of worm cast on the growth and mycorrhizal colonization of two ornamental plants. S Indian Hort 35:433-437.

Meshram N, Badge S, Bhongle SA, Khiratkar SD (2008). Effect of bio-inoculants with graded doses of NPK on flowering, yield attributes and economics of annual Chrysanthemum. J Soils Crops 18(1):217-220.

Muzain M, Singh DB, Muruli Y, Rashmi C (2004). Effects of different biofertilizer on vegetative growth, spike yield and corn production of gladiolus Cv. 'Snow Princes'. National Symp Rec Trends and Future strategies in Orna Hort 1-4.

Narasimha Raju S, Haripriya K (2001). Integrated nutrient management in crossandra (Crosandra infundibuliformis L.) Cv. 'Dindigul Local'. S Indian Hort 49:181.

Nethra (1999). Effect of organic and inorganic fertilizers on growth, yield and post harvest life of China aster. M Sc (Agri) Thesis Univ Agric Sci Dharwad.

Padaganur PG, Mokashi AN, Patil VS (2005). Flowering, flower quality and yield of tuberose (Polianthes tuberosa L.) as influenced by vermicompost, farmyard manure and fertilizers. Karnataka J Agric Sci 18(3):729-734.

Prabhatkumar S, Raghava PS, Mishra RL (2003). Effect of biofertilizers on growth and yield of China aster. J Orna Hort 6(2):85-88.

Singh AK, Ashutosh KM, Rajesh S, Yeshpal S (2003). Effect of organic and inorganic sources of nutrients on flowering attributes in rose. Prog Hort 35(1):78-81.

Singh AK (2005). Response of rose plant growth and flowering to nitrogen, Azotobacter and farm yard manure. J Orna Hort 8(4):296-298.

Sunita HM, Ravihunje, Vyakaranahal BS, Bablad HB (2007). Effect of plant spacing and integrated nutrient management on yield and quality of seed and vegetative growth parameters in African marigold (Tagetes erecta Linn.). J Orna Hort 10(4):245-249.

Swaminathan V, Ramaswamy N, Pallia OA (1999). Effect of Azospirillum, phoshobacteria and inorganic nutrients on the growth and yield of tuberose. S Indian Hort 47(1-6):331334.

Tarrand JJ, Krieg NR, Doberreiner J (1978). A taxonomics study of the Spirillum lipoferum group, with descripction of new genus. Azospirillum gen. Nov and species. Azospirillum lipoferum (Bejerink) Comb. Nov and Azospirillum brasilinese. Sp. Nov. Canadian J Microbio 27:967-980.

Wange SS, Patil PL, Patil JJ (1995). Effect of biofertilizers alone and with nitrogen levels on tuberose Cv. 'Single Petaled'. J Soils Crops 5(2):97-99.

Warade AP, Golliwar VJ, Chopde N, Lanje PW, Thakre SA (2007). Effect of organic manures and bio-fertilizers on growth, flowering and yield of dahlia. J Soils Crops 17(2):354-357. 